\title{
Product range optimization - case study
}

\author{
Simona-Clara Bârsan, Research Institute for Analytical Instrumentation Cluj-Napoca \\ Romania \\ Mihaela-Georgia Sima, Bucharest Chamber of Commerce and Industry, Romania
}

\begin{abstract}
The paper presents the optimizing procedure of the product range manufactured by a company which operates in the area of production and sales of the milling and bakery products. The paper authors have taken this company as an example since the products it manufactures and commercializes address to population and are required to meet both qualitative and quantitative market requirements. After a brief overview of the company, one analyses its production capacity, staff structure and distribution as well as the concern of the company for the employees' training in its activity field, so as to fulfill all the necessary and required conditions for developing a qualitative activity. The analysis continues with: the cost of the product before optimization, software presentation and computerized optimization procedure, the selection of the products to be optimized, data collection, the optimization procedure, results obtaining and analysis, choosing the optimal solution for the analyzed products analysis and for the future competitiveness of the company.
\end{abstract}

\section{Keywords}

management, marketing, production, market, profit

\section{JEL Codes: M 11}

\section{Introduction}

The progress of any society depends to a decisive extent on the efficiency with which its human, natural and financial capabilities resources are used. People have always tried, from each spent unit of labor, human resources or money, to ensure the greatest possible increase of production volume and quality, to obtain increased quantities of material assets and services, which to be later justified by placing them on the market, according to its demands, because only in this way one can achieve strong economic growth, the creation of an advanced economy and, implicitly, default conditions for raising the material and spiritual welfare of the population.

\section{Summarizing the company}

The company is active in the sphere of production and marketing of grain mill and bakery. The production profile is represented by cereals processing, bread making and bakery, pastry and confectionery, as well as food packaging. The trading of the manufactured products is carried out through their own sales centers, private or state users. 
The organizational structure of the company is an essential part of the management system that mostly determines its functionality. In the company's organizational structure, one distinguishes the two main components: management structure and production structure.

a. Management Structure

The General Meeting of Shareholders (GMS) is the governing body of the company, having the role to appoint the Management Board which, in turn, appoints the executive management of the company. In the same order one delegates the competencies as well.

The organizational structure of the company is a hierarchical - functional one.

b. The production structure of the company consists of: grain mill products manufacturing, bread production, specialty bakery manufacturing and pastryconfectionery manufacturing. The company has great potential for production.

\section{Diagnosis of the technical and productive potential}

a. Manufacture of grain mill - production capacity

On the company site one can find: mill I, with a total capacity of $105 \mathrm{t} / 24 \mathrm{~h}$, re-tech; mill II, with a total capacity of $200 \mathrm{t} / 24 \mathrm{t}$, endowed with latest generation equipment, having excellent technical performance provided by the Italian company OCRIM. This mill was put in service in 1996.

Technological manufacturing flow and production resources: the manufacturing process of grain mill products and by-products includes the activities of wheat cleaning, conditioning and milling.

b. Manufacture of bread - production capacities and resources.

In the company there are 2 sections that have bread production as production object, namely: Section I with a capacity of $100 \mathrm{t}$ bread/24 h and Section II with a capacity of 60 $\mathrm{t}$ bread/24 h. Both are equipped with the basic tools needed for good quality production, using raw and auxiliary materials of high quality. One seeks for obtaining a wide range of bread which, along with traditional bread, would satisfy consumer taste and demands.

c. Manufacture of bakery specialties - production capacities and resources.

The production capacity of the workshop is $40 \mathrm{t} / 24 \mathrm{~h}$; it is equipped with the necessary equipment and the manufacturing activity of the specialty bakery involves the use of raw and auxiliary materials. The obtained products are various, such as: traditional bakery specialties (knot-shaped bread, martyrs, paschal) and products for special occasions (requiem, baptism) are products of reference that face successfully with the competition. d. Manufacture of pastry and confectionery - production capacities and resources.

The pastry and confectionery sector has a special section, re-equipped, with a capacity of $18 \mathrm{t} / 24 \mathrm{~h}$, as well as a workshop for the preparation of pie sheets, with adequate facilities. Products obtained: various confectionery products.

Table 1 Diagnosis of human resources management and use

\begin{tabular}{|c|c|c|c|}
\hline \multicolumn{2}{|c|}{ Staff structure } & \multicolumn{2}{c|}{ Staff distribution on activity types } \\
\hline Studies & Share $(\%)$ & Activity & Share (\%) \\
\hline Higher & 7.5 & Management and administration & 17.5 \\
\hline $\begin{array}{c}\text { Secondary and } \\
\text { apprentice }\end{array}$ & 73.8 & Production & 64.5 \\
\hline Gymnasium & 18.7 & Sales and distribution of products & 18.0 \\
\hline TOTAL & 100.0 & TOTAL & 100.0 \\
\hline
\end{tabular}

Source: company's HR department 


\section{Training and development of staff}

The company management has always been concerned by the staff training in occupational skills (apprenticeship) and night school qualification, the staff following training courses organized by specialized bodies such as FIATEST or PURATOS training center.

In order to implement a new Quality Management System inside the company, one has made a series trainings for the staff involved in marketing activities, sales and trading, related to: the client - trial procedure relationship, customer satisfaction, marketing operational procedures; preventive and corrective actions, the control of nonconforming product - general procedures; product maintaining, identification and traceability operational procedures; internal communication - operational procedures; records control- general procedure; data analysis - operational procedures.

Regarding the hygiene - health training of the staff: the persons coming directly or indirectly in contact with the products are regularly trained by empowered institutes regarding the requirements of specific hygiene norms so as to ensure food security products.

\section{Cost per product}

The company management is interested in adopting technical and organizational measures which would determine, on the one hand, the reducing of the product costs and the profitability increase, on the other hand. The costs reducing is determined mainly by the efficient use of material resources, reflected by the specific consumption diminishment, the increase of the production capacity utilization degree, the increase of labor productivity and the elimination of all the causes that generate non-economic consumption. Considering the analysis of the internal and external market, with its related trends, as well as its own production capacity, the company management has proceeded to the optimization, using a computer program, of the range of products to be manufactured and distributed to customers.

\section{Description of the optimization procedure and results:}

In the conditions of a massive development of the informatics systems, an efficient optimization, of economic nature, may not practically take place without the use of specific computer-assisted methods. They enable the development and, ultimately, the solving of complex mathematical models of the modeled processes, correlated with a precise definition of the optimization objectives and by considering the elements or characteristics that restrict the obtaining of some absolute optimum values. With direct reference to the range optimization of some products, one can consider a "radical" solution, namely the products re-designing, taking into account a series of economic, technological, psychological and, ultimately, management criteria, related primarily to:

- a closer approach to the consumer requirements, regarding: quality, optimal weight, quality maintaining in time, purchasing power, modern design which increases the attractiveness of the product;

- efficient use of raw materials, equipment, materials;

- upgrading or introducing new manufacturing processes, possibly patented, by which to achieve an optimal quality /cost ratio. 
This approach is however very complex and goes beyond the present paper. The specific approach used in the paper is the mathematical modeling for a given range of existing products, considered "healthy" or "future", for which one establishes concrete conditions of predictable evolution. The solving of the mathematical model leads to the optimal values of the specific parameters of the considered production which, once accomplished, lead consequently to a specific optimum. The mathematical model is linear and the problem is to find an optimum arising from taking into consideration several objective functions.

The objective function is therefore expressed in that for $\mathrm{N}$ independent variables $\mathrm{x}_{1} \ldots$ $\mathrm{x}_{\mathrm{N}}$, one should maximize (minimize) the following functions:

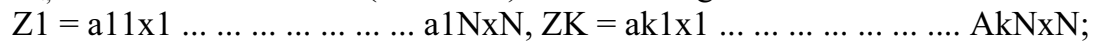

taking into account the primary restrictions: $\mathrm{x}_{1} \geq 0, \ldots \ldots \ldots \ldots \ldots \ldots \mathrm{x}_{\mathrm{n}} \geq 0$, and simultaneously, having in view the additional restrictions $\mathrm{M}=\mathrm{m}_{1}+\mathrm{m}_{2}+\mathrm{m}_{3}$, out of which:

$\mathrm{m}_{1}$ are like: ai $1 \mathrm{x} 1+$ ai $2 \times 2+\ldots \ldots \ldots \ldots$ ainxN $\leq$ bi $(b i \geq 0), \mathrm{i}=1, \ldots \ldots \ldots \mathrm{m}_{1}$;

$\mathrm{m}_{2}$ are like: aj $1 \times 1+$ aj $2 \times 2+\ldots \ldots \ldots$. ajNxN $\geq$ bj $\geq 0, j=m_{1}+1, \ldots . . m_{1}+m_{2}$;

$\mathrm{m}_{3}$ are like: $\mathrm{ak} 1 \mathrm{x} 1+\mathrm{ak} 2 \mathrm{x} 2+\ldots \ldots \ldots . . \mathrm{akNxN}=\mathrm{bk} \geq 0, \mathrm{k}=\mathrm{m}_{1}+\mathrm{m}_{2}+1, \ldots \ldots \ldots \mathrm{m}_{1}+\mathrm{m}_{2}+\mathrm{m}_{3}$.

The set of values $x_{1} \ldots x_{N}$ that satisfies the specified restrictions is called admissible vector and the functions that one wants maximized (or minimized) are called objective functions. Finally, the admissible vector that maximizes (minimizes) the objective functions is called optimal admissible vector.

Overall, the question put in these terms is called multiple objective linear programming (MOLP).

In essence, solving MOLP algorithm is as it follows:

1 - identifying the decision variables of the problem;

2 - identifying the problem objectives and formulate in terms of linear equations;

3 - identifying the problem restrictions and similarly formulate in terms of linear equations;

4 - solving the problem for each of the objectives identified in step 2 so as to determine the optimum values of each objective;

5 - reformulating objectives as goals, using the optimal objective values identified in step 4 as target values;

6 - for each goal, one creates a deviation function that measures the amount through which each given solution deviates from goal;

7 - for each of the functions identified in step 6, one assigns a correspondent share and creates a restriction which requires that the value of the shared deviation function is less than the variable MINIMAX Q;

8 - solving the resulted problem, in order to minimize the value of Q;

9 - checking the solution of the problem. If it is unacceptable, one adjusts the shares from step 7 and then goes to step 8 .

\section{Practical problem of optimizing the structure of the company product range}

Cereals are the most important food for humans. About 55\% of protein, $15 \%$ from fat and $70 \%$ from carbohydrates, totalizing $50-55 \%$ of the calories consumed worldwide are coming from grain. No other food meets so well the human requirements in nutritional and active principles as cereals. Cereal-based foods provide complex carbohydrates, the best source of energy required by the human body, especially for low-fat diets. In addition, they have a rich content of dietary fiber, minerals and vitamins, particularly those in group B. 
In USA, the recommendations for a healthy diet prescribe that 6 up to 11 servings of the daily food consumption should represent bread, cereals, rice and pasta (one serving means a slice of bread, $30 \mathrm{~g}$ of cereals, a cup of cooked rice or pasta).

In our country, according to statistics, $74.5 \%$ of the people living in cities prefer white wheat flour bread and bakery products, that have low content of nutrients and dietary fiber, but which are the cheapest.

Due to a growing concern of the consumers for their health and, implicitly, for a healthy diet, one has registered a bigger and bigger demand for bread and bakery products made of less refined flours, mixed grain (wheat, rye, flax, corn, oats, sorghum, soybeans), containing bran, wheat germs or various seeds, dietetic bread for specific affections (diabetes, nutritional diseases, cardiovascular diseases etc. These products are rich in vegetable fibers and have a lower caloric content. In this context, the company offers its customers a wide range of bread and bakery specialties that have appropriate nutritional properties, meeting the requirements of a healthy diet, but, at the same time, which needs to be optimized, so as to better meet the preferences and demands of the consumers, in terms of quality and quantity.

For these products there are currently significant limitations related, on the one hand, to the relatively limited "absorption capacity on the market" of some of them and, on the other hand, to the restrictions on the storage capacity of products, currently existing in the company. Regarding the first mentioned restriction, this results either from the mentality of consumers and from the important financial limitations of a significant part of the population, leading overall to a massive consumption of white bread at the expense of other kinds.

In the product range optimization, one has established the optimization of 7 products.

For mathematical modeling and implementation of the optimization program, one has used the economic data provided by the company, corresponding to these 7 products. The used economic data referred to: Weight per piece; Wholesale price RON/kg; Current monthly production ( $\mathrm{t}$ ); Direct costs $/ 1000 \mathrm{~kg}(\mathrm{RON})$; Total expenditures $/ 1000 \mathrm{~kg}$ (RON); Workers salaries/1000 kg (RON); Profit/1000 kg (RON).

To optimize the product range, one will calculate the monthly production of each product, corresponding to break-even. The used formula is: $\mathrm{q}=\mathrm{Cf} /(\mathrm{p}-\mathrm{Cv})$, where $\mathrm{q}=$ monthly production corresponding to break-even, $\mathrm{Cf}=$ total fixed costs for the current monthly production; $\mathrm{p}=$ unit price; $\mathrm{Cv}=$ variable costs per unit.

In agreement with the company management, one has established the following optimization objectives, which represent the basis of objective functions modeling:

- Maximization of the profit obtained from making these products;

- Maximization of the workers income;

- Minimization of the total expenditures related to manufacturing products;

The restrictions of the optimization problem consist in two categories of issues:

- Imposing limits on storage capacity for bread and bakery specialties;

- Imposing upper and lower limits for the production of each component of the optimization package to production, dictated by certain considerations regarding the market absorption of the product and the lower limit of product yield.

One has established the following data of the optimization process:

A) Variables:

$\mathrm{X}_{1}=$ quantity (tons) of product $\mathrm{P}_{1}$

$\mathrm{X}_{2}=$ quantity (tons) of product $\mathrm{P}_{2}$

.......

$\mathrm{X}_{7}=$ quantity (tons) product $\mathrm{P}_{7}$

B) Objective functions:

1) Maximization of the total profit 
$\max \mathrm{fl}(\mathrm{x})=162 \mathrm{x}_{1}+64 \mathrm{x}_{2}+774 \mathrm{x}_{3}+184 \mathrm{x}_{4}+251 \mathrm{x}_{5}+96 \mathrm{x}_{6}+1104 \mathrm{x}_{7}$ 2) Maximization of the workers income $\max \mathrm{f} 2(\mathrm{x})=92 \mathrm{x}_{1}+36 \mathrm{x}_{2}+209 \mathrm{x}_{3}+208 \mathrm{x}_{4}+121 \mathrm{x}_{5}+27 \mathrm{x}_{6}+1125 \mathrm{x}_{7}$

3) Minimization of the total expenditures related to manufacturing products $\min \mathrm{f} 3(\mathrm{x})=1242 \mathrm{x}_{1}+438 \mathrm{x}_{2}+5160 \mathrm{x}_{3}+3690 \mathrm{x}_{4}+1538 \mathrm{x}_{5}+660 \mathrm{x}_{6}+1097 \mathrm{x}_{7}$

C) The restrictions of the model:

$\mathrm{C} 1: 1 \mathrm{x}_{1} \geq 0.27$ (profitable minimum monthly production of product $\mathrm{P} 1$ )

$\mathrm{C} 2: 1 \mathrm{x}_{1} \leq 1.10$ (production proposed for optimization of product $\mathrm{P} 1$ )

$\mathrm{C} 3: 1 \mathrm{x}_{2} \geq 0.15$ (profitable minimum monthly production of product $\mathrm{P} 2$ )

C4: $1 \mathrm{x}_{2} \leq 0.60$ (production proposed for optimization of product $\mathrm{P} 2$ )

$\mathrm{C} 5: 1 \mathrm{x}_{3} \geq 2.58$ (profitable minimum monthly production of product $\mathrm{P} 3$ )

C6: $1 \mathrm{x}_{3} \leq 5.50$ (production proposed for optimization of product P3)

C7: $1 \mathrm{x}_{4} \geq 1.23$ (profitable minimum monthly production of product $\mathrm{P} 4$ )

C8: $1 \mathrm{x}_{4} \leq 4.50$ (production proposed for optimization of product P4)

C9: $1 x_{5} \geq 0.67$ (profitable minimum monthly production of product P5)

C10: $1 x_{5} \leq 1.70$ (proposed for optimizing product production P5)

C11: $1 \mathrm{x}_{6} \geq 0.36$ (profitable minimum monthly production of product $\mathrm{P} 6$ )

C12: $1 \mathrm{x}_{6} \leq 1.40$ (production proposed for optimization of product P6)

C13: $1 x_{7} \geq 4.15$ (profitable minimum monthly production of product $\mathrm{P} 7$ )

C14: $1 x_{7} \leq 6.00$ (production proposed for optimization of product P7)

$\mathrm{C} 15: 1 \mathrm{x}_{1}+1 \mathrm{x}_{2}+1 \mathrm{x}_{3}+1 \mathrm{x}_{4}+1 \mathrm{x}_{5}+1 \mathrm{x}_{6}+1 \mathrm{x}_{7} \leq 12$ (maximum storage capacity of Workshop 1 )

\section{Utilization of the WINQSB optimization program and interpretation of} results

After running the WINQSB program (on the Goal Programming module), one has obtained the following results:

Table 2. Obtained results and optimum solution

\begin{tabular}{|l|l|l|}
\hline & Current (RON) & Optimum (RON) \\
\hline Total profit & 2747.24 & 9676.07 \\
\hline Workers income & 2154.50 & 7820.75 \\
\hline Total expenditures & $25,394.57$ & $89.171,00$ \\
\hline
\end{tabular}

Source: results generated by mathematical modulation

The analysis of the obtained results draws the following conclusions regarding the optimal orientation of production:

In general, for the sorts produced in smaller quantities, one requires increases of the current monthly production, as it follows: for $\mathrm{P} 1$, from $0.40 \mathrm{t}$ to $0.67 \mathrm{t}$ - an increase of $0.27 \mathrm{t}(67 \%)$; for P2, from $0.20 \mathrm{t}$ to $0.36 \mathrm{t}$ - an increase of $0.16 \mathrm{t}(80 \%)$; for $\mathrm{P} 3$, from $0.60 \mathrm{t}$ to $1.23 \mathrm{t}$ - an increase of $0.63 \mathrm{t}(105 \%)$; for $\mathrm{P} 4$, from $0.07 \mathrm{t}$ to $0.15 \mathrm{t}-$ an increase of $0.8 \mathrm{t}$ (114\%); for P5, from $0.10 \mathrm{t}$ to $0.27 \mathrm{t}$ - an increase of $1.7 \mathrm{t}(170 \%)$.

2) The optimized value for the monthly production of P6 increases significantly as compared with the current monthly production, namely with $2.32 \mathrm{t}$, respectively from $1.00 \mathrm{t}$ to $3.32 \mathrm{t}(232 \%)$.

3) A more remarkable increase in relative value is observed for product P7, at which the current monthly production of $1.56 \mathrm{t}$ should increase to the optimal value of $6.00 \mathrm{t}$ per month, representing an increase of $4.44 \mathrm{t}(284 \%)$. 
In conclusion, one can note that for all 7 products, the optimized production is higher than the current one, the most significant differences being registered for the assortments produced in greater quantities.

4) For the optimum values obtained using the WINQSB program, one has obtained:

a) a maximum profit of $9,676.07 \mathrm{RON}$, as compared with the current value of $2,747.24$ RON, meaning a profit increase of $6,928.83$ RON (252\%);

b) a $263 \%$ increase of the workers income, respectively from $2,154.5 \mathrm{RON}$ to $7,820.7$ RON;

c) a $251 \%$ increase of the total expenditures, i.e. from 25,394 RON to 89,171 RON.

It is noted that a $251 \%$ of the total expenditures corresponds both to a relatively higher increase of the profit (increased by $252 \%$ ) and to a $263 \%$ increase of the workers income.

5) Having in view the increase, in absolute value of 63.777 RON, of the total expenditures referred to in paragraph 4) c), one requires the company to find financial resources to cover this increase in expenditures. Overall, however, the company will obtain an important increase of profit and workers income.

6) Taking into account the fact that overall production for the assortments proposed for optimization increases from $3.93 \mathrm{t}$ to $12 \mathrm{t}$, one requires the increase of the storage capacity, for a suitable storage of the supplementary production resulted from the optimization process.

7) Since the optimal values for products $\mathrm{P} 6$ and $\mathrm{P} 7$ are significantly higher than the current yields, it is necessary that the company should take appropriate measures towards marketing and promoting such products, so as to lead to their absorption by the market. This thing will be achieved through advertising, publicity etc., the nutritional and diet qualities of the products, benefic for the consumer's health, being presented in an appropriate manner. One should prevent the situation in which the company manufactures these products, profitable in themselves, but fails in saling them.

\section{Conclusions}

The optimization program of the product range has considered a linear mathematical model that used three objective functions considered as the most relevant at company level: maximum profit, maximum workers income, minimum expenditures in which one considered restrictions such as minimum-maximum-type and limited storage capacity for the bakery specialties. The product mix chosen to be optimized includes dietary products that have important contribution of vitamins and fibers useful to human metabolism, corresponding to a healthy diet (P1-P7).

The obtained results show significant increases that can be achieved in order to obtain optimum production for products $\mathrm{P} 6$ and $\mathrm{P} 7$, which indicates that these products are not only "recommended", but also profitable. Moreover, the other products are produced in smaller quantities, and the result of the optimization process has led to less significant changes of the production, as compared to the current one. This can be explained by the fact that the mentality of the consumers has not yet assimilated them to a level which could make them widely profitable. One requires a significant management decision related to the development of these types of products which, potentially, can be substantially more required in terms of an appropriate marketing that would highlight the benefits of their consumption. The obtained optimum has had in view the current possibilities of the company, but for a "future" optimization which considers significant expansion of the product range, the company necessitates an appropriate re-tech. In this respect, one should have in view the utilization degree increase of the equipments, raw 
and auxiliary materials, situation that may significantly change the production /cost ratio for some or most of the considered products.

At the same time, the changing of the population mentality regarding the consumption of such products, in respect of approaching the European trends can bring new elements that will have to be taken into account.

One mentions that the basis of the proposed optimization remain valid, so as the new optimal values, possible to be obtained, will come from the specifications of some new limits of the restrictions related to the optimization problem.

\section{References}

1. Băşanu, Gh.., ş.a., (2004), Managementul aprovizionării şi desfacerii, Ed. Economică, Bucureşti

2. Chira, A., (2005), Sistem de management al siguranței alimentului conform principiilor HACCP, Ed. Conteca, București

3. Demetrescu, M.C., (2001), Metode de analiză în marketing, Ed. Teora, Bucureşti

4. Dumitru, I., (2004), Marketing strategic - o abordare în perspectiva globalizării, Ed. Uranus, București

5. Gheorghiță, M., (2001), Modelarea şi simularea proceselor economice, Ed. ASE, București

6. Kotler, Ph., (1997), Managementul marketingului, Ed. Teora, Bucureşti

7. Naneș, M., (2000), Managementul strategic al întreprinderii şi provocările tranziției, Ed. All Beck, Bucureşti

8. Nicolescu, O., (2002), Strategii manageriale de firmă, Ed. Economică, Bucureşti

9. Săseanu, A.S, (2005), Strategii manageriale în industria de panificație, Ed. Matrix Rom, Bucuresti

10. $x \times x$ Strategia națională de dezvoltare durabilă a agriculturii şi industriei alimentare “Orizont 2025”, www.agriculturaromâniei.ro 